\title{
In vitro Evaluation of Antiproliferative, Lipoxygenase and Xanthine Oxidase Inhibitory Activities of Artemisia nilagirica (C.B.Clarke) Pamp. Leaf Extracts
}

\author{
M. Y. BHAT, M. Z. GUL, M. K. HUSAIN¹ AND I. A. GHAZI*
}

Department of Plant Sciences, School of Life Sciences, University of Hyderabad, Prof. C. R. Rao Road, Gachibowli, Hyderabad, 500 046, ${ }^{1}$ Central Research Institute of Unani Medicine, Erragadda, Hyderabad-500 038, India

Bhat et al.: Cytotoxicity and Inhibition of Proinflammatory Enzymes by Artemisia nilagirica

The current study was performed to screen the extracts of Artemisia nilagirica (C.B. Clarke) Pamp. for antiproliferative and antiinflammatory properties. Antiproliferative activity was assessed using the 3-(4,5-dimethylthiazol-2-yl)-2,5-diphenyltetrazolium bromide assay. Antiinflammatory activity was evaluated in terms of lipoxygenase and xanthine oxidase inhibitory activities. Results indicated that out of the 3 extracts tested, methanol extract was found to inhibit Y79 (human retinoblastoma) and MCF-7 (human breast adenocarcinoma) cell lines. The same extract was also found to inhibit lipoxygenase and xanthine oxidase enzymes in a concentration-dependent manner with an $\mathrm{IC}_{50}$ of $128.20 \pm 3.39$ and $144.23 \pm 2.04 \mu \mathrm{g} /$ $\mathrm{ml}$ for lipoxygenase and xanthine oxidase, respectively. The present study highlighted the antiproliferative potential of the plant against cancer cell lines. The extracts inhibited lipoxygenase and xanthine oxidase enzymes. Therefore, this plant could be a valuable source for anticancer and antiinflammatory molecules.

Key words: Artemisia, inflammation, lipoxygenase, xanthine oxidase, cytotoxic 
Plants are well known as a treasure house of medicinally important secondary metabolites. Since ancient periods and across a number of civilizations, mankind has used this to their advantage to treat a variety of diseases and for maintaining proper health. The purpose of synthesis of secondary metabolites by plants is actually the coordination of biological interactions and defense against infections, predation and herbivory. But, many of these possess a remarkable therapeutic value and serve as preliminary material for the development of agents of modern medicine ${ }^{[1,2]}$. Natural products obtained from plants are well-accepted sources for a number of drugs currently used against several human ailments like cancer. Several plant-based molecules that include vinblastine, vincristine, taxol and camptothecin derivatives are used clinically to cure patients of various types of cancers ${ }^{[3]}$. The pursuit of new anticancer agents from plants is still a necessity to widen the range of availability of more effective and tumor-specific drugs. Biosphere harbors a great plant diversity with estimates of about 2 to 4.5 lakh species of flowering plants present in it. Approaches for selecting any plant for new bioactivity includes either random selection or taking a clue from ethnopharmacology or related traditional knowledge of the concerned plant ${ }^{[4,5]}$.

Lipoxygenase (LOX) enzyme transforms linoleic, arachidonic and other polyunsaturated fatty acids into biologically active metabolites implicated in the inflammation-related and immunological reactions like hydroperoxy fatty acids and leukotrienes ${ }^{[6]}$. The products of this transformation are involved in the pathogenesis of pain, fever and sepsis ${ }^{[7]}$. Likewise, xanthine oxidase $(\mathrm{XO})$ is a complex iron-sulfur flavoprotein that catalyses hydroxylation of hypoxanthine into xanthine and finally xanthine to uric acid ${ }^{[8]}$. Excess production of uric acid results in hyperuricemia and subsequently in its deposition in joints ultimately leading to inflammation with pain ${ }^{[9]}$. XO inhibitors that obstruct the production of uric acid within the body have been used for treating hyperuricemia. However, the currently used XO inhibitors suffer from certain side effects and limitations such as allergic reactions and nephropathy ${ }^{[10,11]}$. In this scenario, the utilization of compounds accessed from medicinal plants signifies an essential source of newer and clinically relevant drugs to cure of disorders arising due to hyperactivity of these enzymes ${ }^{[12]}$.
Artemisia nilagirica has been known to be used in traditional and folk medicine in the form of decoctions and infusions prepared from almost all parts of the plant to treat nervous disorders, gastrointestinal problems, epilepsy, urinary problems, skin disorders and inflammatory problems ${ }^{[13,14]}$. In addition to this, there have been reports of other biological properties from this plant like antioxidant ${ }^{[15]}$, antibacterial ${ }^{[16]}$, cytoprotective ${ }^{[17]}$, anthelminthic, antifungal and antiulcer ${ }^{[13]}$. Essential oil obtained from this plant is also reported to have many medicinal applications ${ }^{[18]}$. The aim of the present study was to screen various extracts of A. nilagirica for antiproliferative activity on human cancer cell lines and inhibition of the enzymes, LOX and XO.

All solvents and chemicals used in the study were purchased from HiMedia and Merck (India). Standard drugs and chemicals were procured from Sigma Aldrich (St. Louis, USA). Roswell Park memorial institute (RPMI-1640), Dulbecco modified Eagle medium (DMEM), antibiotics and fetal bovine serum were obtained from Gibco (Invitrogen, USA). The solvents used in this study were of analytical grade.

The plant material was procured from Central Research Institute of Unani Medicine, Hyderabad, India. The material was properly identified by a taxonomist and a voucher specimen of this plant (UoH/VS/AN-3) has been well-preserved for future reference.

Fresh leaves of $A$. nilagirica were shade-dried completely atroom temperature. The dried leaves $(200 \mathrm{~g})$ were ground to a coarse powder and was extracted with 21 of n-hexane by maceration for $48 \mathrm{~h}$ with constant shaking. The extraction was repeated two more times each time using 21 of fresh $n$-hexane. The extract was filtered through Whatman no.1 paper and concentrated on a rotary evaporator to dryness. The marc was further extracted with absolute methanol $(>98 \%)$ and $70 \%$ alcohol in a similar manner. The extracts were dried, lyophilized and were labelled, hexane extract of A. nilagirica (ANH), methanol extract of $A$. nilagirica (ANM) and $70 \%$ alcoholic extract of $A$. nilagirica

This is an open access article distributed under the terms of the Creative Commons Attribution-NonCommercial-ShareAlike 3.0 License, which allows others to remix, tweak, and build upon the work non-commercially, as long as the author is credited and the new creations are licensed under the identical terms

Accepted 20 February 2019

Revised 29 September 2018

Received 09 August 2018

*Address for correspondence E-mail: irfan@uohyd.ernet.in

Indian J Pharm Sci 2019;81(2):389-395 
(ANA), respectively. Stock solutions of $50 \mathrm{mg} / \mathrm{ml}$ were prepared in DMSO for experiments.

The yield of plant extracts was calculated as: yield (\%) $=\left(\mathrm{W}_{1} / \mathrm{W}_{2}\right) \times 100$, where $\mathrm{W}_{1}$ is the weight of the extract after complete removal of the solvent and $\mathrm{W}_{2}$ is the weight of the dry plant powder. The yield of the extracts was calculated using new powder each time $(n=3)$.

The cell lines, MCF-7 (human breast adenocarcinoma) and Y79 (human retinoblastoma) were acquired from the National Centre for Cell Sciences, Pune, India. MCF-7 cells were cultured in DMEM and Y79 in RPMI 1640 medium complemented with $10 \%$ fetal bovine serum. Culture media contained penicillin (100 units $/ \mathrm{ml})$ and streptomycin $(100 \mu \mathrm{g} / \mathrm{ml})$. These cells were cultured at $37^{\circ}$ in a humidified milieu in a $5 \% \mathrm{CO}_{2}$ incubator.

The extracts of A. nilagirica were examined for antiproliferative activity using 3-(4,5-dimethylthiazol2-yl)-2,5-diphenyltetrazolium bromide (MTT) assay ${ }^{[19]}$. Cells were equally dispensed in triplicate in a 96-well plate at optimized concentrations of $1 \times 10^{5}$ cells $/ \mathrm{ml}$. The culture medium was removed from the wells after $24 \mathrm{~h}$ of incubation. Subsequently, $200 \mu \mathrm{l}$ of fresh medium containing the extracts at increasing concentration $(5-250 \mu \mathrm{g} / \mathrm{ml}$ for MCF-7 and Y79) was added to each well and further incubated for $48 \mathrm{~h}$. After incubation, medium in each well was taken out carefully without disturbing the cells and replaced with fresh media along with $20 \mu \mathrm{l}$ of $5 \mathrm{mg} / \mathrm{ml}$ MTT solution (in sterile filtered phosphate-buffered saline, $\mathrm{pH}$ 7.4). The cells were incubated at $37^{\circ}$ for $4 \mathrm{~h}$, and thereafter the medium from each well was removed and replaced with dimethyl sulfoxide (DMSO, $100 \mu$ l) to solubilize the formazan crystals. A vehicle control of $0.1 \%$ DMSO was also used with all the cell lines. Curcumin was used as a positive control for Y79 and doxorubicin for MCF-7 cells. Finally, the absorbance of the wells was measured at $\lambda 540 \mathrm{~nm}$ in a microplate reader after shaking for $30 \mathrm{~s}$ and the percent cell inhibition was calculated using the formula: $\%$ cell inhibition $=1-$ (OD of sample/OD of control) $\times 100$.

LOX assay was carried out according to the method of Chung et al. with a slight modification in 96 well plate $^{[7]}$. An aliquot of $50 \mu \mathrm{LOX}$ (final concentration, $100 \mathrm{ng} / \mathrm{ml}$ ) in $50 \mathrm{mM}$ Tris $\mathrm{HCl}$ buffer (pH 7.4) was preincubated with $20 \mu \mathrm{l}$ of the extracts or indomethacin $(10-300 \mu \mathrm{g} / \mathrm{ml})$ for $5 \mathrm{~min}$ at $25^{\circ}$. In this experiment, $50 \mu \mathrm{l}$ of LOX solution and $20 \mu \mathrm{l}$ of buffer with
$0.5 \% \mathrm{v} / \mathrm{v}$ DMSO were added to wells as a negative control. The reaction was triggered by adding $50 \mu \mathrm{l}$ of $140 \mu \mathrm{M}$ linoleic acid prepared in the same buffer. This reaction mixture was further incubated in dark for $20 \mathrm{~min}$ at $25^{\circ}$. The reaction was terminated by the addition of $100 \mu 1$ freshly prepared ferric oxidation of xylenol orange (FOX) reagent. The composition of this reagent was sulfuric acid $(30 \mathrm{mM})$, xylenol orange $(100 \mu \mathrm{M})$, iron (II) sulfate $(100 \mu \mathrm{M})$, methanol/water $(9: 1)$. Thereafter, the $\mathrm{Fe}^{3+}$-dye complex was incubated for another $30 \mathrm{~min}$ at $25^{\circ}$ for color development before being measured at $\lambda 560 \mathrm{~nm}$ in a microplate reader (Infinite Pro, Tecan, Switzerland). Blanks contained the enzyme during incubation, but the substrate (linoleic acid) was added only after the FOX reagent. LOX inhibition in the presence of the extracts and standard was calculated according to the formula: $\%$ inhibition of $\operatorname{LOX}=\left(A_{c}-A_{b}\right)-\left(A_{s}-A_{b}\right) /\left(A_{c}-A_{b}\right)$, where $A_{b} ; A_{s}$ and $A_{c}$ are the absorbances of blank, sample and controls, respectively.

The generation of uric acid from xanthine was utilized to determine XO activity by the method of Spanou et al. with minor changes ${ }^{[20]}$. The total reaction mixture of $200 \mu \mathrm{l}$ in the 96 -well plate contained sodium phosphate buffer $(\mathrm{pH} 7.5)$, xanthine $(4.8 \mu \mathrm{M})$ and EDTA $(0.1 \mathrm{mM})$. The extract was added in increasing concentration of $10-400 \mu \mathrm{g} / \mathrm{ml}$. An addition of XO (17.2 $\mathrm{mU}$ in deionized water) was made to initiate the reaction. The optical density was measured at $\lambda$ $295 \mathrm{~nm}$ for $4 \mathrm{~min}$ at room temperature. Allopurinol, a known XO inhibitor, was used as positive control at a concentration of 50-400 $\mu \mathrm{g} / \mathrm{ml}$. A negative control was prepared with the assay mixture without the extract.

The results were presented as mean \pm standard deviation (SD) values derived from independent experiments done in triplicate. $\mathrm{IC}_{50}$ values were determined as the concentrations of the extracts or standards needed to inhibit enzyme activity by $50 \%$. Data calculations and statistical analysis were performed using GraphPad Prism software (version 7.0). Statistical differences among the samples were deduced by proper statistical tests (One-way ANOVA, Tukey's and Student's t-tests). $p$ values $\leq 0.05$ were set as statistically significant.

A wide range of the yields among extracts was observed showing considerable variations depending on the nature of extraction solvent. Maximum yield was for ANM at $9.09 \pm 1.08 \%$ followed ANH at $5.23 \pm$ $0.92 \%$, while the yield of ANA was only $4.13 \pm$ $0.61 \%$. Physical appearance of the extracts was 
somewhat semisolid paste type. The colour of ANH, ANM and ANA was yellowish-green, brownish-green and brown, respectively.

Out of the three extracts ANH, ANM and ANA, only ANH and ANM showed antiproliferative activity in a concentration-dependent manner from 10-250 $\mu \mathrm{g} / \mathrm{ml}$ in most of the cancer cells used in this study. ANA, on the other hand, was least effective in killing the cancer cells and inhibited a negligible percentage of cancer cells even when applied at a higher concentration of $250 \mu \mathrm{g} / \mathrm{ml}$. MCF-7 cells showed a concentrationdependent cell death with ANH and ANM with $87.12 \pm 6.39$ and $96.84 \pm 2.21 \%$ cell death at $250 \mu \mathrm{g} / \mathrm{ml}$, respectively. Y-79 cell line was also affected to a considerable extent by ANM showing 65.79 $6.29 \%$ cell death at $250 \mu \mathrm{g} / \mathrm{ml}$ with an $\mathrm{IC}_{50}$ value of $187.93 \pm 6.74 \mu \mathrm{g} / \mathrm{ml}$. The cytotoxicity due to ANH was lower $(29.14 \pm 4.23 \%)$ even at the highest concentration used in the experiment (fig. 1). The percent inhibition and $\mathrm{IC}_{50}$ of extracts and positive controls are described in Table 1.

The extracts exhibited considerable variation in inhibiting LOX activity. ANM was most effective among the extracts and inhibited LOX activity up to $88.24 \pm 0.46 \%$ at the highest concentration of $300 \mu \mathrm{g} / \mathrm{ml}$ with an $\mathrm{IC}_{50}$ value of $128.20 \pm 3.39 \mu \mathrm{g} / \mathrm{ml}$. ANH also inhibited the activity of LOX although it was lower than that of ANM and its $\mathrm{IC}_{50}$ value was 196.07士 $2.19 \mu \mathrm{g} / \mathrm{ml}$. ANA was found to be the least effective and the highest concentration tested produced only $21.09 \pm 2.01 \%$ inhibition. Indomethacin used as a standard inhibited LOX with an $\mathrm{IC}_{50}$ value of $60.97 \pm 2.31 \mu \mathrm{g} / \mathrm{ml}$. The overall inhibitory of activity of the extracts is depicted in fig. $2 \mathrm{~A}$.

The extracts of $A$. nilagirica also showed considerable variation in inhibiting XO activity. In a manner similar to that observed in the LOX assay. ANH and ANM inhibited XO activity in a concentration-dependent manner. ANM showed the highest activity with an $\mathrm{IC}_{50}$ value of $144.23 \pm 2.04 \mu \mathrm{g} / \mathrm{ml}$. ANH and ANM inhibited XO activity by $20.41 \pm 0.37$ and $80.60 \pm 1.43 \%$ at $400 \mu \mathrm{g} / \mathrm{ml}$ respectively, at the highest concentration tested. ANA was again least effective among the extracts tested and produced only $16.02 \pm 0.79 \%$ inhibition of $\mathrm{XO}$ at $400 \mu \mathrm{g} / \mathrm{ml}$. Allopurinol, an inhibitor of XO gave an $\mathrm{IC}_{50}$ value of $108.74 \pm 3.20 \mu \mathrm{g} / \mathrm{ml}$. The results of this experiment are depicted in fig. 2B.

As per WHO, traditional medicine based on plants is popular in every corner of the world and after realizing the benefits, its uses are rapidly spreading even in developed countries ${ }^{[21]}$. In the contemporary era, plants not only have been a source of drugs for various lifethreatening and other disorders, but several standardized crude extracts obtained from medicinal plants have in many cases been used to cure various ailments and much more showed promising biological activity ${ }^{[22,23]}$. Although several anticancer drugs currently in market trace their basic origin to plants, a good deal of research continues to identify more number of plant species that demonstrate anticancer activity with a huge focus on those being used as herbal remedies by people in developing countries. Most of the plant-based
(A)

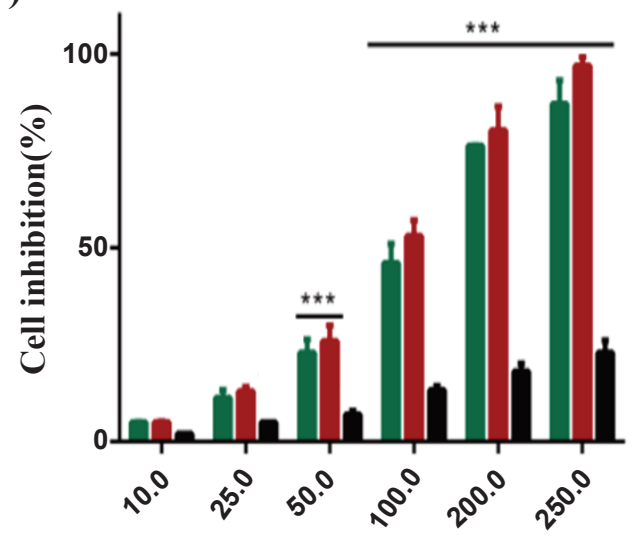

Concentration $(\mu \mathrm{g} / \mathrm{ml})$
(B)

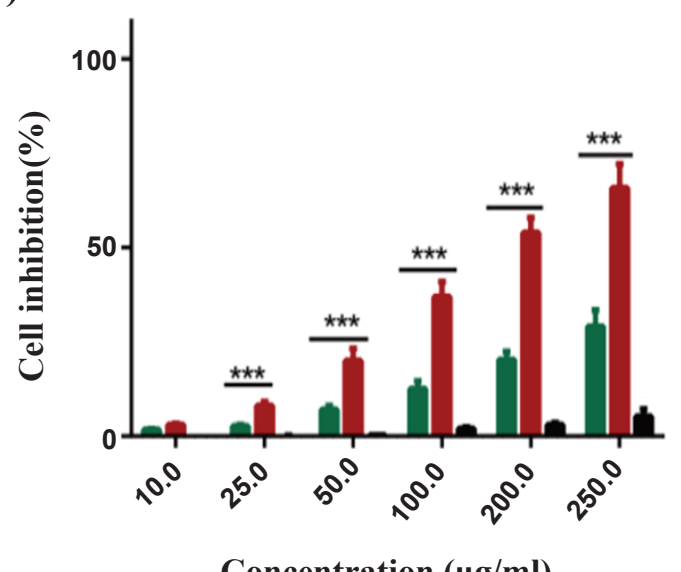

Fig. 1: Cytotoxic activity of $A$. nilagirica extracts against MCF-7 and Y79 cells

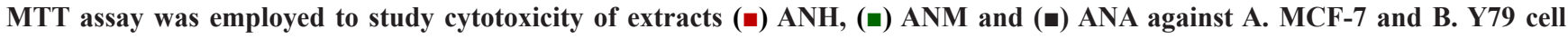
lines. Cytotoxicity was estimated after treating the cells with various concentrations of extracts and incubation for $48 \mathrm{~h}$. Values are mean \pm SD $(\mathbf{n}=3) . * * * \mathbf{p}<0.001$ as compared with control 
(A)

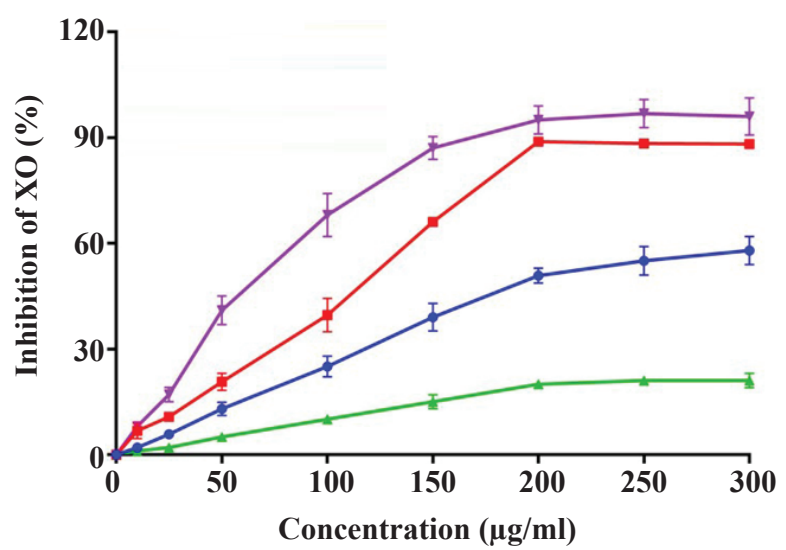

(B)

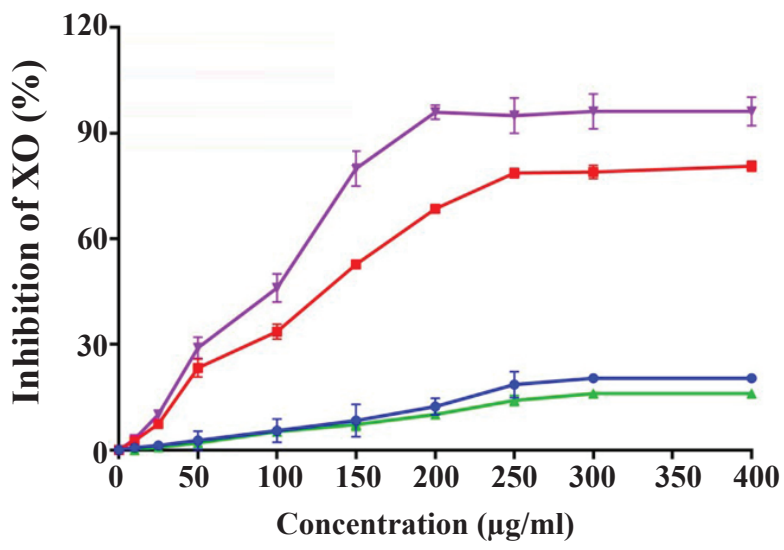

Fig. 2: Inhibitory effects of ANH, ANM and ANA on lipoxygenase and xanthine oxidase

Different concentrations of (-०-) ANH, (- - ANM, (- - ) ANA were studied on the activity of (A) lipoxygenase and (B) xanthine oxidase enzymes in comparison to indomethacin $(-\nabla-)$ and allopurinol $(-\nabla-)$. Results were expressed as mean percent inhibition $\pm \mathrm{SD}, \mathrm{n}=3$

TABLE 1: IC ${ }_{50}$ VALUES FROM MTT ASSAY OF CELL LINES WITH EXTRACTS OF A. NILAGIRICA

\begin{tabular}{cccc}
\hline Cell line & $\begin{array}{c}\text { Extract/ } \\
\text { standard } \\
\text { extracts }\end{array}$ & $\begin{array}{c}\mathrm{IC}_{50} \text { value } \\
(\mu \mathrm{g} / \mathrm{ml})\end{array}$ & $\begin{array}{c}\text { Inhibition } \\
\text { at highest } \\
\text { concentration (\%) }\end{array}$ \\
\hline \multirow{4}{*}{ MCF-7 } & ANH & $104.16 \pm 4.11$ & $87.12 \pm 6.39$ \\
& ANM & $94.82 \pm 3.09$ & $96.84 \pm 2.21$ \\
& ANA & ND & $23.00 \pm 3.09$ \\
& Doxorubicin & $0.76 \pm 0.08$ & $96.28 \pm 3.49$ \\
Y79 & ANH & ND & $29.14 \pm 4.23$ \\
& ANM & $187.93 \pm 6.74$ & $65.79 \pm 6.29$ \\
& ANA & ND & $5.28 \pm 1.92$ \\
& Curcumin & $13.45 \pm 1.24$ & $88.28 \pm 4.79$ \\
\hline
\end{tabular}

Values are expressed as mean \pm SD. ND stands for not determined. Highest concentration used for doxorubicin and curcumin is 1 and $20 \mu \mathrm{g} / \mathrm{ml}$, respectively. Treatments were compared using one way ANOVA and probability values were calculated to less than or equal to 0.05 for these cell lines

chemical entities have an ideal property of being nonlethal to normal cells and more specifically cytotoxic to cancer cells and thus are ideal for drug development ${ }^{[3]}$. Chronic inflammatory disorders include; asthma, diabetes, rheumatoid arthritis, inflammatory bowel diseases, various neurodegenerative diseases and even cancer. The current treatment option is with antiinflammatory drugs, which often is not effective enough, but would result in unendurable side effects like gastrointestinal complications and immunosuppression ${ }^{[24]}$. A number of plants were reported to have been ethnopharmacologically used for management of inflammation-related ailments and injury healing. There is an increased interest in researchers worldwide to find new antiinflammatory remedies, which apart from possessing improved therapeutic index are also comparatively harmless ${ }^{[25]}$. It is generally believed that plant products can exhibit an antiinflammatory action by acting at various stages of inflammation. A significant number of molecules isolated from plants are already in clinical use and many more such as; curcumin, resveratrol and colchicine are in different stages of clinical trials ${ }^{[24]}$. A. nilagirica is an ethnopharmacologically important medicinal plant, which is a component of many Ayurvedic and Unani elixirs and the current study was an attempt to scientifically validate the medicinal claims.

Several in vitro screening methods like enzyme inhibition, cell-based assays have been widely employed for preliminary scientific validation of therapeutic claims of a plethora of medicinal plants used in traditional system of medicine, as food supplements and spices ${ }^{[26,27]}$. In this study with MTT assay, it was demonstrated that ANM was most potent in inhibiting the cell lines in a concentration-dependent manner followed by ANH. However, there is also a significant variation in the sensitivity of cells to different extracts. Y79 cell line was least affected by the extracts even by the most active ANM extract. These observations indicated that the antiproliferative potential with in the same plant depended upon which plant part was extracted and with which solvent ${ }^{[28,29]}$. Moreover, cancer cell lines were sensitive to different plant extracts to different extents. Such variations of cell lines to different extracts are very commonly encountered during cytotoxicity screening ${ }^{[30,31]}$. Previously, certain semi-purified fractions were reported to inhibit monocyte leukaemia cells and certain terpenoids and 
flavonoids were identified in those fractions ${ }^{[32]}$. The cytotoxic components that have been identified in this plant included germacrene, caryophyllene, and borneol, all are components of the essential oil ${ }^{[30]}$. A. nilagirica is rich in phenolics, flavonoids, terpenoids and alkaloids which could contribute to the cytotoxic activity of the extracts as well as responsible for the variations observed in the antiproliferative activity of these extracts ${ }^{[14]}$.

Inhibition of LOX activity could have potential therapeutic applications because leukotrienes play an important role in inflammatory disorders ${ }^{[33]}$. ANH and ANM extracts produced concentration-dependent inhibition of LOX activity and the activity was as good as that of indomethacin. Keeping in view the importance of this enzyme, continual attempts have been made from time to time to identify LOX inhibitors from medicinal plants ${ }^{[7,34]}$. A. nilagirica extracts have been reported to contain phenolics, flavonoids, terpenoids and other secondary metabolites, which could exhibit synergism while inhibiting $\operatorname{LOX}^{[14,35]}$. Hyperactive XO and oxidative stress would lead to increased levels of uric acid in tissue, which could result in rheumatic diseases such as acute inflammatory arthritis and gout $^{[36]}$. ANM extract exhibited good XO inhibitory activity although at a higher concentration of $400 \mu \mathrm{g} / \mathrm{ml}$. A. nilagirica plant has been traditionally known to cure inflammatory complications like arthritic gout and the LOX and XO inhibitory activities observed in this investigation provides a scientific explanation to support the plants use in traditional medicine ${ }^{[37,38]}$.

To conclude, ANM exhibited cytotoxic activity against human breast cancer cells. The extracts also inhibited the enzymes LOX and XO in a concentrationdependent manner. The findings of this study warrant future research for isolation, identification and characterization of chemical constituents of this plant responsible for these activities which could serve as leads for developing better anticancer and antiinflammatory drugs.

\section{Acknowledgements:}

The authors MYB and MZG acknowledge the financial support in the form of Senior Research Fellowship from UGC and CSIR, India respectively. Authors would also like to thank DBT-CREBB, DST-FIST level I \& II, DST-PURSE Phase I \& II and UGC-SAP-CAS, UGCXI plan seed money for supporting infrastructural facilities of Department of Plant Sciences and School of Life Sciences, University of Hyderabad. The authors also acknowledge the financial support provided by University of Hyderabad as UPE-II research grant to IAG lab (UH/UGC/UPE-II/Interface Studies/ Research Projects/R58). The authors also thank Dr. Insaf A. Qureshi, Department of Biotechnology and bioinformatics, School of life sciences, University of Hyderabad for his generous support during the research work.

\section{Conflict of interest:}

Authors have declared that they have no conflict of interest.

\section{REFERENCES}

1. Singh B, Bhat TK, Singh B. Potential therapeutic applications of some antinutritional plant secondary metabolites. J Agric Food Chem 2003;51(19):5579-97.

2. Dias DA, Urban S, Roessner U. A historical overview of natural products in drug discovery. Metabolites 2012;(2):30336.

3. Greenwell M, Rahman PK. Medicinal Plants: Their use in anticancer treatment. Int J Pharm Sci Res 2015;6(10):410312.

4. Fadeyi SA, Fadeyi OO, Adejumo AA, Okoro C, Myles EL. In vitro anticancer screening of 24 locally used Nigerian medicinal plants. BMC Complement Altern Med 2013;13:79.

5. Khattak U, Ullah R, Khan SA, Barkatullah, Ullah S, Saima. Pharmacognostic evaluation and analgesic efficacy of ethanolic extract of Euphorbia dracunculoides L. Pharmacogn J 2017;9(5):644.

6. Sudha A, Srinivasan P. Bioassay-guided isolation, identification and molecular ligand-target insight of lipoxygenase inhibitors from leaves of Anisomeles malabarica R.Br. Pharmacognosy Mag 2014;10(Suppl 3):S596-605.

7. Chung LY, Soo WK, Chan KY, Mustafa MR, Goh SH, Imiyabir Z. Lipoxygenase inhibiting activity of some Malaysian plants. Pharm Biol 2009;47(12):1142-8.

8. Pacher P, Nivorozhkin A, Szabo C. Therapeutic effects of xanthine oxidase inhibitors: renaissance half a century after the discovery of allopurinol. Pharmacol Rev 2006;58(1):87114.

9. Boumerfeg S, Baghiani A, Messaoudi D, Khennouf S, Arrar L. Antioxidant properties and xanthine oxidase inhibitory effects of Tamus communis L. root extracts. Phytother Res 2009;23(2):283-8.

10. Hudaib MM, Tawaha KA, Mohammad MK, Assaf AM, Issa AY, Alali FQ, et al. Xanthine oxidase inhibitory activity of the methanolic extracts of selected Jordanian medicinal plants. Pharmacogn Mag 2011;7(28):320-4.

11. Fagugli RM, Gentile G, Ferrara G, Brugnano R. Acute renal and hepatic failure associated with allopurinol treatment. Clin Nephrol 2008;70(6):523-6.

12. Saeed R, Ahmed D. Bioactive compounds from Carissa opaca roots and xanthine oxidase and alpha-amylase inhibitory activities of their methanolic extract and its fractions in different solvents. Pharmacognosy Res 2014;7(4):295-301.

13. Suresh J, Mahesh NM, Ahuja J, Santilna KS. Review on Artemisia nilagirica (Clarke) Pamp. JBAPN 2011;1(2):97104. 
14. Wright CW. Artemisia. 1st ed. London: CRC Press; 2001.

15. Gul MZ, Bhat MY, Maurya R, Qureshi IA, Ghazi IA. In vitro evaluation of antioxidant and antiproliferative activities of Artemisia nilagirica extracts. Indian J Pharm Sci 2017;79(6):872-84.

16. Ahameethunisa AR, Hopper W. Antibacterial activity of Artemisia nilagirica leaf extracts against clinical and phytopathogenic bacteria. BMC Complement Altern Med 2010;10:6.

17. Bhat MY, Gul MZ, Khan N, Qureshi IA, Ghazi IA. Cytoprotective activity and anti-inflammatory properties of Artemisia nilagirica (Clarke) extracts-A study with macrophages. JBAPN 2017;7(3):228-44.

18. Stappen I, Wanner J, Tabanca N, Wedge DE, Ali A, Khan IA, et al. Chemical composition and biological effects of Artemisia maritima and Artemisia nilagirica essential oils from wild plants of western Himalaya. Planta Med 2014;80(13):107987.

19. Bhat MY, Gul MZ, Lohamror LR, Qureshi IA, Ghazi IA. An in vitro study of the antioxidant and antiproliferative Properties of Artemisia absinthium- A Potent Medicinal Plant. Free Radic Antioxidants 2018;8(1):18-25.

20. Spanou C, Veskoukis AS, Kerasioti T, Kontou M, Angelis A, Aligiannis $\mathrm{N}$, et al. Flavonoid glycosides isolated from unique legume plant extracts as novel inhibitors of Xanthine oxidase. PLoS One 2012;7(3):e32214.

21. Atanasov AG, Waltenberger B, Pferschy-Wenzig EM, Linder $\mathrm{T}$, Wawrosch C, Uhrin P, et al. Discovery and resupply of pharmacologically active plant-derived natural products: A review. Biotechnol Adv 2015;33(8):1582-614.

22. Amara AA, El-Masry MH, Bogdady HH. Plant crude extracts could be the solution: extracts showing in vivo antitumorigenic activity. Pak J Pharm Sci 2008;21(2):159-71.

23. Palombo EA. Traditional medicinal plant extracts and natural products with activity against oral bacteria: Potential application in the prevention and treatment of oral diseases. Evid Based Complement Alternat Med 2011;2011:680354.

24. Robert F, Ilse Z. Plant-derived anti-Inflammatory compounds: Hopes and disappointments regarding the translation of preclinical knowledge into clinical progress. Mediators Inflamm 2014;2014:146832.

25. Shaikh RU, Pund MM, Gacche RN. Evaluation of antiinflammatory activity of selected medicinal plants used in Indian traditional medication system in vitro as well as in vivo. J Tradit Complement Med 2016;6(4):355-361.

26. Gul MZ, Attuluri V, Qureshi IA, Ghazi IA. Antioxidant and $\alpha$-glucosidase inhibitory activities of Murraya koenigii leaf extracts. Pharmacogn J 2012;4(32):65-72.
27. Gul MZ, Chandrasekaran S, Bhat MY, Maurya R, Qureshi IA, Ghazi IA. Antioxidant and enzyme inhibitory activities of Cissampelos pareira L. leaf extracts. Ann Phytomed 2016;5(1):91-98.

28. Gul MZ, Ahmad F, Kondapi AK, Qureshi IA, Ghazi IA. Antioxidant and antiproliferative activities of Abrus precatorius leaf extracts - an in vitro study. BMC Complement Altern Med 2013;13:53.

29. Bhat MY, Gul MZ, Maurya R, Khan N, Qureshi IA, Ghazi IA. Growth inhibition and apoptosis inducing effects of Artemisia absinthium L. fractions on chronic myeloid leukemia (K562) cells. JBAPN 2018;8(2):70-89.

30. Saleh AM, Aljada A, Rizvi SA, Nasr A, Alaskar AS, Williams JD. In vitro cytotoxicity of Artemisia vulgaris L. essential oil is mediated by a mitochondria-dependent apoptosis in HL60 leukemic cell line. BMC Complement Altern Med 2014; 14:226.

31. Roslen NA, Alewi NA, Ahamada H, Rasad MS. Cytotoxicity screening of Melastoma malabathricum extracts on human breast cancer cell lines in vitro. Asian Pac J Trop Biomed 2014;4(7):545-8.

32. Gul MZ, Chandrasekaran S, K M, Bhat MY, Maurya R, Qureshi IA, Ghazi IA. Bioassay-guided fractionation and in vitro antiproliferative effects of fractions of Artemisia nilagirica on THP-1 cell line. Nutr Cancer 2016;68(7):121024.

33. Eshwarappa RS, Ramachandra YL, Subaramaihha SR, Subbaiah SG, Austin RS, Dhananjaya BL. Anti-lipoxygenase activity of leaf gall extracts of Terminalia chebula (Gaertn.) Retz. (Combretaceae). Pharmacognosy Res 2016;8(1):78-82.

34. Schneider I, Bucar F. Lipoxygenase inhibitors from natural plant sources. Part 1: Medicinal plants with inhibitory activity on arachidonate 5-lipoxygenase and 5-lipoxygenase[sol] cyclooxygenase. Phytother Res 2005;19(2):81-102.

35. Shinta M, Berna E, Katrin. Antioxidant activity and lipoxygenase enzyme inhibition assay with total flavonoid content from Garcinia hombroniana Pierre Leaves. Pharmacogn J 2017;9(2):267-72.

36. Kostić DA, Dimitrijević DS, Stojanović GS, Palić IR, Đorđević AS, Ickovski JD. Xanthine oxidase: Isolation, assays of activity, and inhibition. J Chem 2015;2015:294858

37. Mandal SC, Mandal V, Konishi T. Natural Products and Drug Discovery: An integrated approach. 1st ed. Amsterdam, Netherlands: Elsevier; 2018.

38. Staff TP. PDR for Herbal Medicines. 3rd ed. Montvale, NJ: Thomson; 2004. 